\title{
Hubungan Motivasi dan Kepuasan Relawan pada Organisasi Seni
}

\author{
Jangkung Putra Pangestu \\ Pendidikan Seni Musik Universitas Negeri Yogyakarta \\ jangkungputrapangestu@gmail.com
}

\begin{abstract}
Abstrak
Relawan merupakan asset penting pada organisasi seni. Memahami motivasi dan kepuasan sangat diperlukan dalam merekrut maupun mengelola relawan. Tujuan utama penelitian ini adalah untuk mengetahui hubungan motivasi dan kepuasan relawan selama mengikuti kegiatan sukarela di tiga organisasi seni yaitu Komunitas Gayam 16, Jogja-NETPAC Asian Film Festival (JAFF) dan Yayasan Biennale Yogyakarta. Metode yang digunakan adalah metode survey dengan kuesioner Volunteer Functions Inventory (VFI) yang disusun oleh Clary, dkk (1998). Data diperoleh dari 179 responden dengan cara menyebarkan kuesioner cetak dan kuesioner elektronik (GoogleForm). Data yang terkumpul, dianalisis menggunakan metode analisis deskriptif, korelasi product moment Kruskall-Wallis dan Mann-Whitney. Hasil penelitian menunjukkan bahwa dari enam dimensi motivasi yang diajukan, fungsi pemahaman, fungsi karir dan fungsi peningkatan, mempunyai peran penting dalam memotivasi seseorang menjadi relawan, serta mempunyai hubungan yang kuat dan signifikan dengan kepuasan. Motivasi relawan juga dapat dipengaruhi oleh jenis organisasi dan faktor demografi. Temuan ini dapat menjadi bahan pertimbangan bagi para pengelola untuk mendapatkan relawan yang sesuai dengan organisasi. Pengelola dapat menyusun sistem pengelolaan relawan yang efektif meskipun hasil dari penelitian ini tidak bisa digeneralisir. Penelitian ini diharapkan menjadi titik awal bagi penelitian berikutnya mengenai kesukarelawanan pada organisasi seni.
\end{abstract}

Kata kunci: relawan, organisasi seni, motivasi, kepuasan, volunteer functions inventory

(vfi)

\begin{abstract}
Volunteers are the most important assets of an arts organization. Understanding motivation and satisfaction is needed in recruiting and managing the volunteer. The main purpose of this research is to find out the correlation between volunteer motivation and satisfaction in three arts organizations, Komunitas Gayam 16, Jogja-NETPAC Asian Film Festival and Yayasan Biennale Jogja. The method used is survey method using Volunteer Function Inventory (VFI) developed by Clary et al. (1998). Data from 179 respondents were collected through an hard copy and online questionnaires managed through GoogleForm. The collected data were analyzed using discriptive statistics, product moment correlation, Kruskall-Wallis dan Mann-Whitney. The result indicated that among six motivation functions, the understanding, career and enhancement are the most popular reasons for volunteering and significanly related to volunteer satisfaction level. Volunteer motivation can also be influenced by organization type and demographic factors. This findings have implication for arts manager to get the type of volunteer for their particular type of organization. The arts manager can develop effectively volunteer management system. This study serves as a starting point for more research on volunteerism in arts organizations.
\end{abstract}

Keywords: volunteer, art organization, motivation, satisfaction, volunteer functions inventory ( $v f i$ ) 


\section{Pendahuluan}

Mempunyai anggaran yang minim memaksa organisasi seni untuk mencari jalan keluar yang tepat demi kelangsungan hidup sebuah organisasi. Merekrut relawan merupakan salah satu cara untuk menghadapi keterbatasan anggaran namun mendapatkan tenaga kerja tanpa mengeluarkan anggaran untuk memberikan upah. Relawan adalah seseorang yang menyumbangkan waktu, tenaga, dan talentanya untuk memenuhi suatu kebutuhan masyarakat tanpa mengambil keuntungan finansial atas sumbangannya tersebut (Musick, 2008). Relawan berbeda dengan pekerja berbayar (karyawan) meskipun keduanya merupakan tenaga kerja pada sebuah organisasi. Relawan mempunyai komitmen yang tinggi terhadap organisasi karena pelayanannya lebih berbasis pada nilai dibandingkan dengan pekerja berbayar (Cuskelly, McIntyre dan Boag, 1998). Meskipun relawan merupakan pekerja yang tidak berbayar, namun ada beberapa hal yang perlu diperhatikan dalam mengelolanya. Memahami motivasi relawan secara mendalam sangat diperlukan bagi pengelola organisasi dalam merekrut maupun mempertahankan relawan (Bang dan Ross, 2004). Hal tersebut merupakan tugas organisasi yang sulit dalam menyelami relawan karena setiap individunya mempunyai motivasi yang berbeda-beda tergantung konteks dan kesempatannya mengikuti kegiatan sukarela (Clary dkk, 1998).

Peran relawan dirasa begitu penting dan mampu memberikan banyak keuntungan bagi organisasi. Beberapa organisasi sangat menggantungkan pelayanan dari para relawan. Dalam sebuah survei terhadap 237 manajer seni di Australia, Palmer (1997) menemukan bahwa 50\% organisasi memiliki lebih dari 10 (sepuluh) relawan dan 10\% organisasi memiliki 100 (seratus) relawan atau lebih. Begitu juga dengan survei Volunteer and Donors in Arts and Culture Organization in Canada in 2010 menemukan bahwa relawan yang terlibat pada organisasi seni dan budaya di Kanada berjumlah 764.000 orang dan menyumbangkan waktunya sebanyak 97 juta jam di tahun 2010. Mereka terlibat dalam mengelola, mengawasi atau mengkoordinasi segala aktivitas atau event organisasi (Canada Council of The Art, 2010). Selanjutnya, organisasi teater lokal di UK sangat menggantungkan peran dari relawan. Keterlibatan relawan sangat menguntungkan organisasi karena mereka dapat berperan sebagai pendukung teater lokal dan menambah pendapatan organisasi (Bussell \& Forbes, 2005; 2006).

Setiap kelompok relawan mempunyai ciri khas sendiri-sendiri yang tidak bisa disamakan dengan relawan lainnya. Wymer dkk (2000) mengemukakan bahwa relawan seni berbeda dengan relawan dibidang lain. Relawan seni mempunyai komitmen yang lebih tinggi dan menyumbangkan waktunya lebih banyak dibandingkan dengan relawan di bidang lainnya karena motivasinya lebih bersifat altruistik daripada egoistik. Relawan seni juga tidak mempunyai hubungan dengan kepentingan agama (church attendance atau church member). Selanjutnya, Bussell and Forbes $(2005,2006)$ berpendapat bahwa relawan merupakan kelompok yang tidak homogen, artinya terdiri dari berbagai macam umur dan latar belakang yang berbeda-beda dengan pengalaman dan keterampilan yang berbeda pula. Oleh karena itu, penting sekiranya bagi manajer organisasi seni untuk memahami relawan dalam merekrut dan mengelola relawan, bukan hanya jenis relawan secara umum, namun relawan seperti apa yang cocok untuk organisasinya (Wymer dkk, 2000). Hal ini 
menjadi satu catatan penting bagi para pengelola organisasi karena dalam merekrut relawan juga memerlukan anggaran yang tidak sedikit.

Penelitian ini membahas tentang motivasi relawan di tiga organisasi seni, yaitu Komunitas Gayam 16, Jogja-NETPAC Asian Film Festival (JAFF) dan Yayasan Biennale Yogyakarta. Ketiga organisasi tersebut dipilih karena dengan sengaja merekrut atau membuka kesempatan bagi siapa saja untuk terlibat dalam kegiatan kesukarelawanan, memiliki relawan dengan jumlah yang memungkinkan untuk melakukan survei, mencari keberagaman data pada tiga organisasi seni yang fokusnya berbeda dan tentunya bersedia membantu penelitian ini. Selain itu, ketiganya juga sangat mengharapkan keterlibatan relawan dalam mengelola organisasi. Tujuan utama penelitian ini adalah untuk mengetahui hubungan antara motivasi relawan dan kepuasan relawan selama mengikuti kegiatan sukarela. Metode yang digunakan dalam penelitian ini adalah metode kuantitatif dengan menggunakan kuesioner Volunteer Functions Inventory (VFI) yang disusun oleh Clary dkk (1998).

Telah banyak penelitian yang dilakukan sebagai upaya untuk menjelaskan motivasi relawan. Dengan mengkategorikan berbagai macam jenis motivasi diharapkan mampu mempermudah dalam memahami motivasi relawan. Ada empat model pengkategorian motivasi relawan, yaitu model ekamatra, model dwimatra, model trimatra dan model multi matra (Widjaja, 2010). Model ekamatra artinya motivasi relawan hanya terdiri dari satu kategori saja atau motivasi relawan dapat dikelompokkan menjadi satu kategori. Motivasi relawan tidak bisa dikategorikan menjadi beberapa kategori (misalnya altruistik dan egoistik) namun hanya bisa dikategorikan menjadi satu kategori saja sebagai hasil dari penggabungan berbagai motif (Cnaan dan Goldberg-Glen, 1991). Motivasi altruistik adalah motivasi yang berbasis pada nilai, bersifat instrinsik dan berguna untuk kepentingan orang lain, misalnya membantu orang lain atau membantu masyarakat. Sedangkan motivasi utilitarian adalah motivasi yang bersifat egoistis, ekstrinsik, dan berguna untuk kepentingan dirinya sendiri, misalnya seseorang menjadi relawan karena ingin memperoleh pengalaman, ketrampilan dan pengetahuan dari kegiatan kesukarelawanan yang diikuti.

Model dwimatra membagi motivasi relawan menjadi dua kategori. Ada dua macam model two-dimentional. Model dwimatra yang pertama yaitu mengkategorikan motivasi relawan menjadi motivasi altruistik dan motivasi egoistik (Frisch dan Gerrard, 1981). Motivasi altruistik adalah motivasi yang berbasis pada nilai dan berguna untuk kepentingan orang lain, misalnya membantu orang lain atau membantu masyarakat. Sedangkan motivasi egoistik adalah motivasi yang bersifat utilitarian yang berguna untuk kepentingan dirinya sendiri, misalnya seseorang menjadi relawan karena ingin memperoleh pengalaman, ketrampilan dan pengetahuan dari kegiatan kesukarelawanan yang diikuti. Model dwimatra yang kedua adalah mengkategorikan motivasi relawan menjadi motivasi intrinsik dan ekstrinsik (Finkelstien, 2009). Motivasi intrinsik adalah motivasi yang muncul dari dalam diri sendiri sedangkan motivasi ekstrinsik adalah motivasi yang muncul dari luar atau adanya pengaruh dari luar.

Model trimatra membagi motivasi relawan menjadi tiga kategori, yaitu purposive/normatif/altruistik, material/utilitarian dan solidaritas/afektif/sosial (Monga, 2006). Purposive/normatif/altruistik adalah motivasi yang disebabkan atas dasar kepedulian dengan orang lain, misalnya aksi atau dukungan terhadap masyarakat atau terhadap 
lingkungan. Material/utilitarian adalah motivasi yang disebabkan atas dasar keinginan untuk memperoleh penghargaan finansial, misalnya gaji atau upah. Solidaritas/afektif/sosial adalah motivasi yang disebabkan oleh interaksi sosial, hubungan interpersonal dan pertemanan.

Model multi-dimensional membagi motivasi relawan menjadi lebih dari tiga kategori. Model ini diperkenalkan oleh Clary dkk (1998) dan disebut sebagai Volunteer Function Inventory (VFI). VFI melihat motivasi relawan dari perspektif psikologis. Seseorang bersedia menjadi relawan dengan alasan untuk memenuhi kebutuhan psikologisnya. Model ini menggunakan pendekatan teori fungsi untuk mengetahui motivasi seseorang yang terlibat dalam kegiatan kesukarelawanan. Ada enam motivasi fungsional yang berhasil diidentifikasi, yaitu fungsi sosial, nilai, karir, pemahaman, perlindungan, dan fungsi peningkatan. Fungsi sosial adalah untuk mengembangkan dan memperkuat ikatan sosial, fungsi nilai adalah untuk mengekspresikan nilai-nilai yang berkaitan dengan altruistik dan kemanusiaan bagi orang lain, fungsi karir adalah untuk memperbaiki prospek karir dan pekerjaan, fungsi pemahaman adalah untuk mencari pengetahuan yang baru dan pengalaman secara langsung, fungsi perlindungan adalah untuk melindungi dari masalah pribadi dan fungsi peningkatan adalah untuk menumbuhkan serta mengembangkan ego. Dari penelitian Clary, dkk (1998) VFI menggambarkan berbagai motivasi yang berbeda pada kegiatan kesukarelawanan dan menunjukkan bahwa motivasi orang untuk menjadi sukarelawan bersifat unik dan beragam.

Motivasi relawan juga dapat dipengaruhi oleh karakteristik demografi dari relawan itu sendiri dan faktor-faktor yang lain. Barron dan Rihova (2011) menyatakan bahwa karakteristik demografi mempunyai pengaruh terhadap motivasi relawan. Dengan kata lain bahwa motivasi relawan akan berbeda-beda tergantung dengan karakteristik demografi relawan itu sendiri. Motivasi relawan berbeda-beda sesuai dengan umurnya. Relawan organisasi seni yang berusia 18-19 tahun cenderung dimotivasi oleh fungsi sosial sedangkan pada usia lima puluh tahunan, fungsi perlindungan merupakan yang paling utama Hyun (2013). Barron dan Rihova (2011) menemukan bahwa relawan muda pada festival seni lebih cenderung mempunyai motivasi utilitarian. Bussell dan Forbes (2005) menemukan bahwa relawan muda mempunyai keinginan untuk mengembangkan ketertarikannya dibidang seni dan karimya di teater (pengajar teater, pelukis, kru), hobinya (bergabung dengan opera lokal atau teater amatir), dan/atau mempunyai hubungan dengan teater dunia untuk mendapatkan pekerjaan (seperti menjadi aktor profesional). Hal ini sesuai dengan pernyataan Musick (2007) bahwa bertambahnya umur (penuaan) berarti mengubah agenda sosial. Seseorang yang umurnya tergolong dewasa awal, ketertarikan utamanya yaitu membangun hubungan sosial dan membangun hubungan interpersonal. Pada dewasa tengah, ketertarikannya lebih cenderung untuk menemukan rasa dari tujuan (a sense of purpose) dan lebih berkomitmen dengan masyarakat. Sedangkan pada dewasa akhir, ketertarikannya bukan lagi tentang masa depan, namun cenderung pada hal-hal yang bersifat emosional dan memperkuat ikatan sosial.

Jenis kelamin merupakan faktor kedua yang mampu mempengaruhi motivasi relawan. Motivasi relawan berbeda-beda sesuai dengan jenis kelaminnya. Hasil review yang dilakukan oleh Widjaja (2010) pada beberapa penelitian yang menggunakan VFI, menunjukkan bahwa fungsi karir lebih condong dalam mempengaruhi motivasi relawan 
laki-laki dibandingkan dengan relawan perempuan. Selanjutnya, tingkat pendidikan mampu mempengaruhi seseorang untuk menjadi relawan. Hyun (2013) menemukan bahwa fungsi pemahaman, peningkatan dan nilai merupakan faktor utama yang mempengaruhi seseorang yang sudah memperoleh gelar sarjana untuk menjadi relawan. Sedangkan relawan yang hanya lulusan SMA, fungsi peningkatan pemahaman dan sosial merupakan faktor yang mendorong mereka untuk menjadi relawan.

Motivasi relawan dapat dipengaruhi juga oleh konteks maupun jenis organisasi. Hwang (2010) motivasi relawan olahraga dengan relawan music cenderung sama. Namun, perbedaannya terlihat pada konteksnya. Relawan music lebih berantusias mengikuti kegiatan kesukarelawanan karena musik berkaitan langsung dengan psikologisnya. Relawan akan senantiasa lebih tertarik dengan jenis organisasi tertentu yang menurut mereka sesuai dengan kesukaannya. Barron dan Rihova (2011) motivasi relawan dapat dipengaruhi oleh jenis organisasi (misi dan lingkungan) yang mereka inginkan. Relawan akan lebih termotivasi jika misi sebuah organisasi sesuai dengan pemikirannya. Lingkungan pada organisasi juga berpengaruh terhadap motivasi relawan. Relawan yang merasakan kenyamanan pada sebuah organisasi maka ia akan terus menjadi relawan. Disatu sisi, jenis pekerjaan yang ditawarkan juga mampu mempengaruhi motivasi relawan (Barron dan Rihova, 2011).

Selanjutnya, kepuasan pada penelitian ini dapat diartikan sebagai perasaan puas seseorang dengan pengalamannya selama mengikuti kegiatan kesukarelawanan. Miller (1985) mengungkapkan bahwa seseorang menjadi relawan karena ingin mendapatkan kepuasan tersendiri yang tidak bisa didapatkan pada pekerjaan yang berbayar. Mengikuti kegiatan kesukarelawan dapat meningkatkan kepuasan batin karena telah memberikan sesuatu yang berharga bagi orang lain. Kepuasan mempunyai peran yang signifikan dalam hal kesukarelawanan sebagai jembatan antara merekrut dan mempertahankan relawan (Clary, 1998). Barron dan Rihova (2011) menyatakan bahwa kesesuaian, kepuasan dan upaya retensi telah terbukti sebagai aspek penting dalam proses retensi relawan dan semuanya tidak dapat dipisahkan.

Relawan akan merasa tidak puas dan meninggalkan organisasi secara perlahan jika organisasi tidak mempunyai program dan layanan yang memuaskan. Mengetahui kepuasan relawan tidak hanya memungkinkan organisasi untuk merekrut relawan secara efektif saja, namun juga berguna untuk mengelola dan mempertahankan relawan yang sudah ada, termasuk keterampilan dan keaktifannya (Bussell dan Forbes, 2002). Pengelola organisai kiranya perlu untuk menyiapkan segala sesuatu untuk mendukung kepuasan relawannya. Pengalaman yang menyenangkan pada kegitan kesukarelawanan secara tidak langsung dapat meningkatkan kepuasan dan kesenangan pribadi relawan (Miller, 1985). Mengidentifikasi tingkat kepuasan relawan merupakan hal penting dalam mengelola relawan dan membutuhkan pengukuran yang reliabel untuk memprediksi manfaat yang diperoleh relawan (Hyun, 2013).

Kepuasan memiliki hubungan dengan motivasi maupun manfaat yang didapatkan relawan dari kegiatan kesukarelawanan. Bang dan Ross (2004) mengungkapkan bahwa ada hubungan antara motivasi dan kepuasan relawan. Kepuasan relawan disebabkan karena kebutuhan psikologisnya terpenuhi ketika mengikuti kegiatan kesukarelawanan dan ketika relawan merasa puas maka mereka akan bersedia menjadi relawan lagi. Kesesuaian antara 
motivasi dan manfaat yang diperoleh dapat mempengaruhi tingginya tingkat kepuasan relawan dan rendahnya turnover dalam merekrut relawan (Barron dan Rihova, 2011). Clary, dkk (1998) motivasi dan manfaat berhubungan dengan intensi relawan untuk menjaga keberlangsungan relawan di masa mendatang. Houle dkk (2005) menemukan bahwa penugasan relawan yang berhubungan dengan ketertarikan individual dan motif dalam segala aktivitas yang mereka lakukan dapat menambah tingginya tingkat kepuasan. Tschirhart (2001) juga menemukan bahwa relawan yang mendapatkan tugas sesuai dengan tujuan awalnya mempunyai tingkat kepuasan yang tinggi dan intensi yang besar untuk kembali mengikuti aktivitas kesukarelawanan pada event tahunan. Farrel dkk (1998) kepuasan terbentuk karena relawan merasakan pengalaman mengikuti kegiatan kesukarelawanan secara aktual yang berhubungan dengan motivasi.

Keterlibatan relawan pada bidang seni memainkan peran yang sangat penting. Kelompok maupun organisasi seni menggantungkan pelayanan dari para relawan. Steur (1997) dalam Wymer dan Brudney (2000) beberapa kelompok seni tidak bisa hidup tanpa relawan. Wymer dan Brudney (2000) organisasi seni sangat tergantung pada relawan sebagai sumber daya. Bussell dan Forbes (2002) dalam penelitiannya di organisasi teater di UK mengungkapkan bahwa organisasi seni merekrut relawan untuk mendukung teater lokal, menambah pendapatan organisasi dan sangat menggantungkan peran dari relawan. Korza (2007) dalam Hyun (2013) mengemukakan bahwa relawan merupakan salah satu sumber daya penting pada organisasi seni. Relawan memberikan dukungan dan layanan penting pada kebutuhan organisasi. Dalam aspek yang lain, relawan mampu mengurangi anggaran organisasi dalam hal promosi terhadap masyarakat karena relawan mampu berperan sebagai penghubung antara organisasi dan masyarakat (Bayer, 2007 dalam Hyun, 2013). Alexander (1996) dalam Wymer dan Brudney (2000) relawan sangat penting untuk kesehatan dan mensukseskan ekologi pada seni. Hal tersebut membuktikan bahwa relawan merupakan sumber daya yang sangat penting bagi organisasi seni dalam menjalankan visi misi organisasi.

Organisasi seni merasa sangat terbantu dengan keberadaan relawan. Relawan benarbenar meringankan tugas pengelola dalam mengelola organisasi. Mereka bersedia melakukan apapun demi kelangsungan organisasi. Bussell dan Forbes $(2005,2006)$ relawan pada organisasi teater di UK juga ikut mengoperasikan teater seperti terlibat sebagai pemain drama, pemain musik, pantomim, tim artistik serta menjadi front of house (menjual tiket, mengantarkan pengunjung pada tempat duduknya, menyediakan kopi dan menjual merchandise). Begitu juga yang terjadi pada organisasi seni amatir atau semi profesional, relawan juga melakukan acting, directing, menari bahkan membuat musik (Steur, 1997).

Relawan juga sangat berguna bagi sebuah organisasi seni jika dilihat dari sisi pemasaran. Smith dan Santandreu (1997) menyatakan bahwa ada dua pelanggan pada museum, yaitu klien dan donatur. Klien adalah pengunjung sedangkan donatur adalah relawan, dimana mereka menyumbangkan waktu dan keahliannya. Bussell dan Forbes (2006) meskipun pengunjung dan penonton diperlukan pada museum dan organisasi seni namun organisasi juga harus menjalin hubungan dengan semua orang yang terlibat, misalnya relawan. Smith dan Santandreu (1997) menyatakan bahwa dalam museum seni, pemasaran terhadap relawan merupakan fungsi manajerial yang sangat penting. Bussell 
dan Forbes (2005) kesuksesan organisasi dalam mengelola relawan dapat dilihat dari membangun dan mengembangkan hubungan antara relawan dan organisasi. Mengelola hubungan merupakan hal yang terpenting dalam mengelola teater. Oleh karena itu, penting kiranya bagi para pengelola organisasi seni untuk mengetahui alasan keterlibatan mereka pada organisasi seni (Wymer dan Brudney, 2000).

Bidang seni mempunyai daya tarik tersendiri bagi para relawan. Hwang (2010) menjadi relawan musik lebih menarik daripada menjadi relawan olahraga. Mereka beranggapan bahwa musik bukan sekedar hiburan namun sebagai cara untuk memahami identitas dan pengalaman pribadi serta membantu setiap individu berkomunikasi dengan orang lain. King (1989) dalam Wymer (2000) menyatakan bahwa seseorang bersedia menjadi relawan seni karena ia percaya pada seni tersebut. Barron dan Rihova (2011) motivasi utama relawan muda bersedia menjadi relawan festival sulap adalah adanya sesuatu yang menarik atau ketertarikan individu pada sulap, mendapatkan pengalaman kerja yang dapat dimasukkan ke dalam CV (riwayat hidup) untuk menunjang karirnya di masa depan dan mempersiapkan diri memasuki pasar tenaga kerja. Bussell dan Forbes (2005) motivasi relawan pada organisasi teater di UK adalah untuk memenuhi kebutuhan sosial dan psikologi. Relawan ingin meningkatkan kehidupan sosialnya (bertemu dengan orang lain, datang ke tempat asing dan senang berbincang dengan orang lain) atau diizinkan berpartisipasi di bidang seni sesuai kesukaannya (menggambar di teater dan bertemu dengan aktor).

Selanjutnya, beberapa peneliti menggunakan Volunteer Function Inventory (VFI) untuk mengungkap motivasi relawan pada bidang seni. Hyun (2013) menemukan bahwa fungsi pemahaman, nilai dan peningkatan merupakan motivasi utama pada relawan episodik organisasi seni di Amerika. Chen (2014) menemukan bahwa motivasi relawan museum dan galeri seni di New Zealand didorong oleh fungsi nilai, pemahaman, dan perlindungan. Menonjolnya fungsi nilai sangat mungkin terjadi karena mayoritas respondennya berusia diatas 60 tahun dan mereka sudah pensiun dari pekerjaan. Hal ini menjadi bukti bahwa VFI benar-benar reliabel meskipun digunakan untuk meneliti relawan pada bidang seni.

\section{Metode Penelitian}

Penelitian ini menggunakan pendekatan survei. Penelitian dilakukan di tiga organisasi seni yang terletak di Yogyakarta, yaitu Komunitas Gayam 16 (musik), JAFF (film) dan Yayasan Biennale Yogyakarta (seni rupa). Subyek pada penelitian ini adalah relawan yang tergabung dalam Komunitas Gayam 16, JAFF maupun Yayasan Biennale Yogyakarta. Sedangkan waktu peneltian dilakukan selama 8 bulan, yaitu dari bulan Agustus 2016 - April 2017. Selanjutnya, peneltian ini menggunakan teknik convenience sampling. Sampel yang diambil adalah seseorang yang secara resmi terdaftar sebagai relawan, mengikuti proses dari pendaftaran hingga mengikuti kegiatan kesukarelawanan dan aktif menjadi relawan selama dua tahun belakang. Karena relawan bersifat datang dan pergi maka aktif selama dua tahun yang dimaksud adalah pernah menjadi relawan antara tahun 2015-2017 meskipun hanya sebentar. Adapun jumlah relawan yang bersedia menjadi sampel berjumlah 179 orang dari jumlah total sebanyak 225 orang dengan rincian sebagai berikut: relawan 
Komunitas Gayam 16 sebanyak 65 orang, relawan JAFF sebanyak 63 orang dan relawan Yayasan Biennale Yogyakarta sebanyak 51 orang.

Alat pengumpulan data berupa kuesioner Volunteer Function Inventory (VFI) yang diterjemahkan ke dalam Bahasa Indonesia dan telah diuji validitas maupun reliabilitasnya. Kuesioner bagian pertama berisi pertanyaan mengenai profil pribadi responden, yaitu nama respoden, nama organisasi, jenis kelamin, usia, pekerjaan dan pendidikan terakhir. Bagian kedua berisi pertanyaan mengenai faktor yang mempengaruhi relawan untuk bergabung ke dalam organisasi yang berjumlah 30 item dan kepuasan yang dirasakan selama menjadi relawan yang berjumlah 5 item yang diukur menggunakan skala likert dengan lima interval. Kuesioner dibagikan secara langsung kepada responden dan dibagikan secara online dengan bantuan GoogleForm.

Metode analisis yang akan digunakan dalam penelitian ini adalah analisis deskriptif, analisis korelasi dan uji beda. Analisis deskriptif dilakukan untuk melihat karakteristik responden dengan cara mencari prosentasenya, mengetahui faktor pendukung pada relawan dari enam dimensi motivasi dan melihat tingkat kepuasan pada relawan dengan cara melihat nilai meannya. Analisis korelasi produk moment dilakukan untuk melihat besarnya koefisien korelasi antar variabel penelitian. Koefisien korelasi memperlihatkan ada atau tidaknya korelasi antar variabel penelitian. Uji beda dilakukan untuk melihat perbedaan motivasi antarorganisasi, jenis kelamin, usia dan pendidikan menggunakan Kruskall-Wallis dan Mann-Whitney. Uji Kruskall-Wallis digunakan untuk uji beda berdasarkan organisasi dan usia. Sedangkan uji Mann-Whitney digunakan untuk uji beda berdasarkan jenis kelamin dan pendidikan.

\section{Hasil dan Pembahasan}

Perlu digarisbawahi bahwa karakteristik resonden pada penilitian ini mengacu pada keadaan sekarang dan bukan keadaan diawal mereka menjadi relawan. Gambaran umum relawan seni pada penelitian ini adalah perempuan, berumur 21-25, pendidikan terakhir SMA dan berprofesi sebagai pelajar/mahasiswa. Namun yang perlu diperhatikan adalah selisih antara jenis kelamin dan tingkat pendidikan tidak terlalu banyak dan signifikan. Perihal umur, perempuan 57\% dan laki-laki 43\% serta pendidikan terakhir SMA 47\% dan $\mathrm{S} 1 / \mathrm{S} 2 / \mathrm{S} 3 \quad 45 \%$. Hal ini dapat ditafsirkan bahwa sebenarnya mereka adalah kelompok yang homogen. Artinya, kegiatan kesukarelawan pada organisasi seni sama-sama diminati oleh orang yang berjenis kelamin perempuan maupun laki-laki dan berada pada rentang umur 2125 tahun. Selanjutnya, tingkat pendidikan relawan adalah SMA dan/atau S1/S2/S3 dan berprofesi sebagai pelajar/mahasiswa. Peneliti berasumsi bahwa mereka yang tingkat pendidikannya SMA karena mereka masih belum lulus kuliah. Sedangkan mereka yang sudah lulus S1 kemungkinan masih dalam tahap menyelesaikan kuliah untuk jenjang S2/S3.

Di sisi lain, relawan muda juga dapat menimbulkan masalah bagi organisasi dan perlu diperhatikan. Peneliti berasumsi bahwa mereka bersedia menjadi relawan karena masih muda dan berstatus pelajar/mahasiswa. Tidak menutup kemungkinan jika mereka nanti sudah bertambah umur dan mempunyai pekerjaan tetap, mereka tidak bersedia lagi menjadi 
relawan. Hal ini sesuai dengan Reis, dkk (1998) menyatakan bahwa banyaknya relawan yang keluar (high rates of dropout) dapat menjadi masalah yang kronis pada pelayanan kesehatan di Indonesia. Bertambahnya umur (penuaan) berarti mengubah agenda sosial. Seseorang yang umurnya tergolong dewasa awal, ketertarikan utamanya yaitu membangun hubungan sosial dan membangun hubungan interpersonal. Pada dewasa tengah, ketertarikannya lebih cenderung untuk menemukan rasa dari tujuan (a sense of purpose) dan lebih berkomitmen dengan masyarakat. Sedangkan pada dewasa akhir, ketertarikannya bukan lagi tentang masa depan, namun cenderung pada hal-hal yang bersifat emosional dan memperkuat ikatan sosial (Musick, 2007).

Selanjutnya, dari enam dimensi motivasi yang diajukan, fungsi pemahaman $(\mathrm{M}=$ $4,20 ; r=0,786)$, fungsi karir $(M=3,90 ; r=0,685)$ dan fungsi peningkatan $(M=3,89$; $\mathrm{r}=0$,683) mempunyai peran penting dalam memotivasi seseorang untuk menjadi relawan. Penemuan ini konsisten dengan prinsip utama Volunteer Function Inventory (VFI) bahwa setiap orang memiliki motivasi yang berbeda untuk berpartisipasi dalam kegiatan kesukarelawanan yang sama. Clary dkk (1998) dan Clary \& Snyder (1999) menyatakan bahwa diantara enam fungsi motivasi yang teridentifikasi, setidaknya dua fungsi dapat memotivasi seseorang untuk menjadi relawan dan merasa puas dengan pengalamannya mengikuti kegiatan kesukarelawanan. Dengan kata lain, ketiga fungsi tersebut harus dianggap sebagai factor pendorong seseorang terlibat dalam kegiatan kesukarelawanan pada organisasi seni. Selain itu, penemuan ini juga ikut andil dalam rangka memperluas penelitian Clary dkk (1998) karena penelitian ini fokus terhadap relawan pada organisasi seni dimana organisasi-organisasi tersebut dengan sengaja membuka kesempatan bagi siapa saja yang bersedia menjadi relawan.

Fungsi pemahaman yang dimaksud dalam penelitian ini adalah kegiatan kesukarelawan merupakan cara seseorang untuk menambah pengetahuan dan pengalaman baru atau melatih ketrampilan yang mungkin tidak bisa diterapkan pada bidang yang lain. Seseorang merasa bahwa dengan menjadi relawan maka ia akan mendapatkan suatu pandangan atau perspektif baru mengenai berbagai hal, terutama kesenian. Relawan akan mampu melihat segala sesuatu secara lebih luas atau dari berbagai macam sudut. Kegiatan kesukarelawanan membuka kesempatan untuk belajar bagaimana menangani berbagai macam orang. Orangorang yang berada dalam sebuah organisasi tentunya memiliki sifat dan latar belakang berbeda, misalnya berhubungan dengan seniman. Dengan menjalin komunikasi, maka para relawan dapat mempelajari lebih dalam tentang karakteristik seniman dan bagaimana menjalin komunikasi dengan mereka.

Selanjutnya, relawan ingin mengekplorasi kemampuan pribadi yang belum pernah dilakukan sebelumnya. Misalnya, kemampuan berbahasa asing. Karena ketiga organisasi tersebut melibatkan orang-orang asing maka relawan diwajibkan untuk berkomunikasi dengan bahasa inggris misalnya. Relawan juga ingin mengetahui lebih dalam tentang organisasi misalnya tujuan organisasi dan tujuan dari diadakannya kegiatan kesukarelawanan. Nantinya relawan akan dapat membedakan antara organisasi seni dengan organisasi yang lainnya. Selain itu, relawan ingin belajar sesuatu secara langsung. Relawan merasa bahwa kegiatan tersebut merupakan kesempatan untuk mengembangkan keterampilan dan menambah pengetahuan. Hal ini menjadi satu catatan penting bagi para pengelola dimana para relawan dapat belajar berbagai hal dan mendapatkan pengetahuan 
yang baru dari kegiatan kesukarelawanan. Sebelum merekrut relawan, pengelola harus mampu meyakinkan para calon-calon relawan bahwa mengikuti kegiatan kesukarelawanan dapat menambah pengalaman dan ketrampilan serta menunjukkan bahwa kegiatan tersebut adalah bagian dari pembelajaran. Temuan ini sesuai dengan temuan Bussel \& Forbes (2005) dan Hyun (2013) relawan pada organisasi seni ingin meningkatkan kehidupan sosialnya misalnya dengan bertemu orang lain dan belajar suatu hal yang baru.

Fungsi karir menduduki peringkat yang kedua setelah fungsi pemahaman. Fungsi karir yang dimaksud dalam penelitian ini adalah kegiatan kesukarelawanan merupakan cara seseorang untuk memperbaiki prospek karir atau pekerjaan. Para relawan merasakan bahwa karir mereka akan menjadi lebih baik setelah mengikuti kegiatan kesukarelawanan. Dengan mengikuti kegiatan sukarelawanan mereka dapat menambah kenalan baru yang berpengaruh terhadap karirnya. Mereka mendapatkan informasi tentang lowongan pekerjaan atau justru diajak untuk ikut bekerja dengan kenalan barunya. Kegiatan sukarelawanan memungkinkan seseorang untuk menjelajahi pilihan karir yang berbeda. Misalnya, relawan lebih menikmati pekerjaan yang diberikan oleh pengelola daripada bidang yang sedang mereka geluti. Pengalaman mengikuti kegiatan sukarelawanan juga dapat dimasukkan pada CV mereka. Mereka menganggap bahwa kegiatan kesukarelawanan merupakan pengalaman sangat penting untuk dicatat pada $\mathrm{CV}$ mereka yang mana dapat berpengaruh ketika mereka mendaftar kerja.

Selanjutnya, relawan merasa bahwa kegiatan yang mereka ikuti dapat mensukseskan pekerjaan yang dipilih. Misalnya, relawan yang memilih untuk menjadi perupa. Dalam kegiatan tersebut ia ditugaskan untuk membuat instalasi pada sebuah pertunjukan. Selain itu, kegiatan kesukarelawanan memungkin para relawan untuk membantu mendapatkan pekerjaan sesuai yang diinginkan. Sebagai contoh, seseorang yang berkeinginan untuk menjadi manajer seni. Dengan mengikuti kegiatan tersebut ia dapat mengetahui lebih banyak tentang pekerjaan manajer seni dan masuk ke dalam lingkup mereka. Temuan ini perlu diperhatikan lebih lanjut oleh para pengelola organisasi karena para relawan berharap bahwa karirnya akan meningkat setelah mengikuti kegiatan kesukarelawanan. Perlu kiranya para pengelola ikut memikirkan karir para relawan. Temuan ini sependapat dengan apa yang ditemukan oleh Bussell \& Forbes (2005) dan Barron \& Rihova (2011) bahwa motivasi relawan seni adalah untuk mendapatkan pengalaman kerja yang dapat dimasukkan kedalam CV (riwayat hidup) untuk menunjang karirnya di masa depan dan mempersiapkan diri memasuki pasar tenaga kerja.

Peringkat yang ketiga yaitu fungsi peningkatan. Fungsi peningkatan yang dimaksud adalah kegiatan kesukarelawanan merupakan cara untuk menumbuhkembangkan ego. Dengan kata lain, kegiatan kesukarelawanan dapat mengembangkan diri seseorang secara psikologis. Relawan menganggap bahwa kegiatan kesukarelawanan merupakan cara untuk mendapatkan teman. Teman yang dimaksud disini adalah orang lain yang mempunyai ketertarikan sama dibidang seni dan dimungkinkan menjalin hubungan pertemanan. Kegiatan kesukarelawanan memungkinkan seseorang untuk meningkatkan harga diri. Mereka merasa bahwa apa yang dilakukan berarti dan berharga untuk orang lain. Pada akhirnya para relawan juga merasakan bahwa dirinya menjadi lebih baik dari sebelumnya.

Selanjutnya, relawan merasa bahwa dirinya penting. Apa yang mereka kerjakan merupakan suatu pencapaian, pengakuan dan penghargaan yang lebih pada bidang seni 
daripada dibidang lain. Relawan juga merasakan bahwa dirinya dibutuhkan. Meskipun hanya sebagai relawan, namun pengetahuan dan ketrampilannya di bidang lain diapresiasi oleh anggota organisasi yang lain. Hal ini membuat mereka merasa bahwa apa yang dilakukannya tidak sia-sia dan semakin bersemangat. Temuan ini sesuai dengan temuan Bussell dan Forbes (2005) dan Hyun (2013) yang menemukan bahwa motivasi relawan seni adalah untuk memenuhi kebutuhan psikologisnya.

Penelitian ini juga berusaha untuk membedakan enam fungsi motivasi berdasarkan jenis organisasi, jenis kelamin, usia dan pendidikan. Pada jenis organisasi, perbedaan yang signifikan terdapat pada fungsi karir dan organisasi JAFF mempunyai nilai mean yang paling tinggi diantara yang lain. Dengan kata lain, fungsi karir berperan penting dalam mendorong seseorang untuk menjadi relawan pada organisasi tersebut. Para relawan beranggapan bahwa menjadi relawan JAFF (film) dapat memperbaiki prospek karirnya. Penemuan ini sesuai dengan Barron dan Rihova (2011) yang menyatakan bahwa jenis organisasi dapat mempengaruhi motivasi seseorang untuk menjadi relawan.

Selanjutnya, rentang usia memiliki perbedaan yang signifikan pada fungsi sosial. Fungsi sosial cenderung dimiliki oleh relawan yang berusia antara 26-30 tahun. Mereka lebih mementingkan fungsi sosial daripada fungsi yang lain, meskipun fungsi yang lainnya juga dirasa penting. Hal ini sesuai dengan pernyataan Musick (2007) bahwa bertambahnya umur (penuaan) berarti mengubah agenda sosial. Seseorang yang umurnya tergolong dewasa awal, ketertarikan utamanya yaitu membangun hubungan sosial dan membangun hubungan interpersonal. Pada dewasa tengah, ketertarikannya lebih cenderung untuk menemukan rasa dari tujuan (a sense of purpose) dan lebih berkomitmen dengan masyarakat. Sedangkan pada dewasa akhir, ketertarikannya bukan lagi tentang masa depan, namun cenderung pada hal-hal yang bersifat emosional dan memperkuat ikatan sosial. Di sisi lain, jenis kelamin dan tidak pendidikan tidak menunjukkan perbedaan yang signifikan. Artinya, tidak terjadi perbedaan motivasi yang dilihat dari jenis kelamin maupun tingkat pendidikan.

Pembahasan berikutnya yaitu mengenai variabel kepuasan. Kepuasan yang dimaksud pada penelitian ini mempunyai arti bahwa seseorang merasa puas setelah mengikuti kegiatan kesukarelawan di organisasi seni. Dari hasil analisis diskriptif variabel kepuasan diperoleh nilai mean sebesar 4,15. Berdasarkan hasil tersebut, seluruh responden dapat dikatakan puas dengan apa yang mereka dapatkan selama mengikuti kegiatan kesukarelawanan pada organisai seni. Hal ini menjadi keuntungan bagi pengelola organisasi karena jika relawan merasa puas maka para relawan akan melanjutkan kegiatan tersebut atau bersedia menjadi relawan lagi. Seperti yang telah disinggung pada bahasan sebelumnya, kepuasan mempunyai hubungan yang kuat dan signifikan dengan fungsi pemahaman, karir dan peningkatan. Selain menjadi faktor pendorong, ketiga dimensi tersebut mempunyai hubungan yang kuat (kemungkinan besar) dengan kepuasan. Sedangkan tiga dimensi yang lain, fungsi nilai, sosial dan fungsi perlindungan, keduanya bukan berarti tidak mempunyai korelasi dengan kepuasan. Akan tetapi berdasarkan nilai koefisien korelasi, ketiganya mempunyai korelasi yang lemah dibandingkan dengan ketiga dimensi yang lain dan tidak menjadi faktor yang penting. Temuan ini sesuai dengan Clary, dkk (1998) dan Farrel, dkk (1998) yang menyatakan bahwa kepuasan disebabkan karena para 
relawan mendapatkan banyak manfaat dari kegiatan kesukarelawan yang berhubungan dengan motivasi.

\section{Kesimpulan}

Penelitian ini bertujuan untuk mengetahui motivasi dan kepuasan relawan pada organisasi seni. Hasil penelitian menunjukkan bahwa relawan seni tergolong muda dan bersifat homogen. Artinya, perempuan dan laki-laki sama-sama mempunyai minat menjadi relawan, berumur 21-25 tahun, tingkat pendidikan SMA atau S1/S2/S3 dan berstatus sebagai pelajar/mahasiswa. Temuan ini menambah referensi pada kasus kesukarelawanan, khususnya kesukarelawanan pada organisasi seni. Faktanya, pada kasus ini peneliti menemukan bahwa relawan organisasi seni bersifat homogen.

Selanjutnya, penelitian ini menggunakan Volunteer Function Inventory (VFI) untuk mengeksplor motivasi dan kepuasan relawan. Hasil penelitian menunjukkan bahwa motivasi dan kepuasan memiliki korelasi yang posistif dan signifikan dengan kepuasan. Motivasi relawan terlibat dalam organisasi seni didorong oleh fungsi pemahaman, fungsi karir dan fungsi peningkatan. Hal ini menyatakan bahwa mereka bersedia menjadi relawan pada organisasi seni karena didasari keinginan untuk menambah pengetahuan, meningkatkan karir dan mencukupi kebutuhan psikologisnya sendiri. Di samping itu, jenis organisasi dan factor demografi dapat mempengaruhi motivasi seseorang untuk menjadi relawan. Motivasi Relawan JAFF (Film) cenderung untuk memenuhi fungsi karir dan motivasi relawan yang berusia 26-30 tahun cenderung untuk memenuhi fungsi sosial.

Perihal kepuasan, para relawan merasa puas dengan pengalamannya selama mengikuti kegiatan kesukarelawanan pada organisasi seni. Para relawan menikmati dan mendapat banyak manfaat dari kegiatan tersebut. Seperti yang telah disinggung sebelumnya, fungsi pemahaman, karir dan peningkatan berkorelasi positif dan signifikan dengan kepuasan. Dengan kata lain, fungsi nilai, sosial dan peningkatan bukan berarti tidak berkorelasi dengan kepuasan namun korelasinya lemah.

Temuan pada penelitian ini dapat menjadi titik awal bagi para pengelola untuk mendapatkan relawan yang sesuai dengan organisasi. Pengelola dapat menyusun sistem pengelolaan relawan yang efektif meskipun hasil dari penelitian ini tidak bisa digeneralisir. Wymer dan Brudney (2000) mengungkapkan bahwa penting sekiranya bagi manajer organisasi seni untuk memahami relawan alam merekrut dan mengelola relawan, bukan hanya jenis relawan secara umum, namun relawan seperti apa yang cocok untuk organisasinya.

Penelitian ini mungkin tergolong unik karena menemukan bahwa mayoritas relawan tergolong muda dan bersifat homogen. Mereka bersedia menjadi relawan karena untuk memenuhi fungsi pemahaman, karir dan peningkatan. Temuan ini juga harus diperhatikan oleh para pengelola dimana para relawan mengharapkan bahwa dengan menjadi relawan dapat menambah pengetahuan, meningkatkan karir dan mencukupi kebutuhan psikologisnya. Sebelum merekrut relawan, pengelola perlu menjelaskan tentang manfaat yang akan diperoleh kepada calon relawannya. Hal ini menghindari adanya kekecewaan dan turnover pada relawan. Selain itu, perlu kiranya para pengelola untuk 
mengadakan pelatihan. Pelatihan penting dilakukan supaya relawan benar-benar dapat menyelesaikan tugas yang telah diberikan mengingat pelatihan merupakan sesuatu yang sangat bermanfaat untuk menambah keterampilan relawan.

\section{Kepustakaan}

Bang, Hyejin dan Ross, Stephen D. 2004. Volunteer Motivation and Satisfaction. https://pdfs.semanticscholar.org/57bc/d374bf289b02f99651d06adda4bdde4208f5.p df

Barron, P., \& Rihova, I. 2011. Motivation to volunteers: A case study of the Edinburgh International Magic Festival. International Journal of Event and Festival Management, 2(3), 1-1.

Bussell, H. and Forbes, D. 2002. Understanding the volunteer market: The what, where, who and why of volunteering. International Journal of Nonprofit and Voluntary Sector Marketing, 7 (3), pp.244-257.

Bussell, H., \& Forbes, D. 2005. Volunteer management in arts organizations: A case study and managerial implications. International Journal of Arts Management, 9(2), $1-10$.

Bussell, H., \& Forbes, D. 2006. Making Friends: volunteering in art marketing. International Journal of Nonprofit and Voluntery Sector Marketing.

Canada Council of the Arts. 2010. Volunteers and donors in arts and culture organizations in Canada in 2010. Statistical insights on the arts vol. 11 no. 3.

Chen, Xiaohua. 2014. Understanding Volunteers in Cultural Tourism Organizations in New Zealand: Exploring Demographics and Motivational Factors. Dissertation. Aucland University of Technology.

Clary, E. G., Snyder, M., Ridge, R. D., Copeland, J., Stukas, A. A., Haugen, J., \& Miene, P. 1998. Understanding and assessing the motivations of volunteers: A functional approach. Journal of Personality and Social Psychology, 74(6), 1516-1530.

Clary, E. G., \& Snyder, M. 1999. The Motivations to Volunteer: Theoretical and Practical Considerations. Current directions in psychological science, 8(5), 156-159.

Cnaan, R. A., \& Goldberg-Glen, R. S. 1991. Measuring motivation to volunteer in Human Services. Journal of Applied Behavioral Science, 27(3), 269-284.

Cuskelly, Graham. McIntryre, Norman dan Boag, Alistair. 1998. A Longitudinal Study of the Development of Organizational Commitment amongst Volunteer Sport Administrators. Journal of Sports Management.

Farrel, Jocelyn M., Johston, Margaret E., dan Twynam, G David. 1998. Volunteer Motivation, Satisfaction, and Manageent at an Elite Sporting Competition. Journal of Sports Management, 12, 288-300.

Finkelstien, M. A. 2009. Intrinsic vs. extrinsic motivational orientations and the volunteerprocess. Personality and Individual Differences, 46(5-6), 653-658.

Frisch, M. B., \& Gerrard, M. 1981. Natural helping systems: A survey of Red Cross volunteers. American Journal of Community Psychology, 9(5), 567-579.

Houle, B.J., Sagarin, B. J., \& Kaplan, M. F. 2005. A functional approach to volunteerism: Do volunteer motives predict task preference? Basic and Applied Social Psychology, 27(4), 337-344.

Hwang, J. 2010. Does sport really matter to volunteers? Implications from an empirical comparison between sport volunteers and non-sport volunteers (Doctoral dissertation). Florida State University, Tallahassee, FL. 
Hyun O, Ji. 2012. Understanding and Assesing Functional Motivations to Episodic Volunteers in Arts Organizations (Doctoral dissertation). Florida State University, Tallahassee, FL.

Miller, L. E. 1985. Understanding the motivation of volunteers: An examination of personality differences and characteristics of volunteers" paid employment. Nonprofit and Voluntary Sector Quarterly, 14(2-3), 112-122.

Monga, Manjit. 2006. Measuring motivation to volunteer for special events. Journal of Event Management, 10(1), 47-61.

Musick, Marc A dan John Wilson. 2008. Volunteers a social profile. Indiana University Press.

Nichols, Bonnie. 2007. Volunteers with arts or cultural organizations: A 2005 profile (Research Report No. 95). Retrieved from National Endowment for the Arts.

Palmer, I. 1997. Arts Management Cutback Strategies: A Cross-Sector Analysis. Nonprofit Management and Leadership, Vol. 7, no 3, p. 271-290.

Reis, Thomas., Elder, John., Satoto., Kodyat, Benny A., dan Palmer, Anne. 1998. An Examination of the Performance and Motivation of Indonesian Village Health Volunteers. International Quarterly of Community Health Education. Pp.19-27.

Smith, S.C. dan J.R. Santandreu. 1997. Marketing in the nonprofit sector - The uniquee case of art museums. Journal of nonprofit and public sector marketing, Vol. 5, No

2, p. 77-90.

Tschirhart, M., Mesch, D. J., Perry, J. L., Miller, T. K., \& Lee, G. 2001. Stipended volunteers: Their goals, experiences, satisfaction, and likelihood of future service. Nonprofit and Voluntary Sector Quarterly, 30(3), 422-443

Widjaja, Emmeline. 2010. Motivation behind Volunteerism. CMC Senior Theses. Paper 4. Wymer, W.W., Jr., \& Brudney, J. L. 2000. Marketing management in arts organizations: Differentiating Arts and culture volunteers from other volunteers. International journal or arts management, 2(3), 40-52. 